\title{
Moderating Effect of Social Uncertainty between Capital Budgeting Practices and Performance
}

\author{
Lingesiya Kengatharan \\ Department of Financial Management, University of Jaffna, Sri Lanka \\ E-mail: lingesiya@yahoo.com
}

Received: October 2, 2017 Accepted: October 25, 2017 Published: November 12, 2017

doi:10.5296/ijafr.v7i2.11936

URL: https://doi.org/10.5296/ijafr.v7i2.11936

\begin{abstract}
Capital budgeting is crucial in order for companies to sustain themselves, survive and flourish in markets and to increase shareholders' wealth. The performance of a firm depends on its effective investment decisions. Investing in the 'right' project has an influence on the success of the firm and its future growth. Even though risk and uncertainty factors carefully considered in investment decision making. Therefore, aim of this study was to evaluate the moderating effect of uncertainty between capital budgeting practices and performance based on Sri Lankan emerging market. The data were garnered from primary data and secondary data sources. The primary data were collected from 186 CFOs working in companies in Sri Lanka using self-administered questionnaires. The questionnaire was piloted with a sample of five CFOs. The secondary data were mainly collected from CSE via the Bloomberg website/annual reports for the 5 years period. In order to evaluate the moderating effect of uncertainty between capital budgeting practices and performance, social uncertainty has been considered in this study. Performance was measured by Tobin_q. Data were analysed using descriptive, inferential and multivariate analysis. Findings of the study revealed that an increased level of social uncertainty weakens the positive relationship between sophisticated capital budgeting practices and Tobin_q. In a similar way, an increased level of social uncertainty weakens the positive relationship between advanced capital budgeting practices and Tobin_q and vice versa. Overall, this study has made contribution as identified the moderating effect of uncertainty between the relationship of capital budgeting practices and performances. In a nutshell, beyond its valuable contribution, this study serves as a springboard for future research in many ways.
\end{abstract}

Keywords: uncertainty, capital budgeting practices and performance 


\section{Introduction}

The survival and vitality of a company is determined by its ability to regenerate itself through the allocation of capital into productive use (Arnold and Hatzopoulos, 2000). Allocating resources among competing investment projects is one of the most critical decisions made by the top management and is of strategic importance, and it invariably involve large sums of money and have a long-term economic life cycle. These decisions are critical to managing strategic change and sustaining long term corporate performance. Nonetheless, current investment markets are evolving within an increasingly volatile and intertwined global network and investments are strongly exposed to uncertainties (Bock and Truck, 2011). Uncertainties could lead to failure of a good investment decision and thus integration of uncertainty with capital budgeting techniques is overarching, on the other hand, often complex (Ghahremani, Aghare and Abedzadeh, 2012). This study focusing to evaluate the moderating effect of uncertainty between capital budgeting practices and performance in Sri Lankan emerging market, where, to the best of the researcher's knowledge, no studies have been conducted to evaluate the moderating effect of uncertainty between capital budgeting practices and performance.

\subsection{Practical Relevance of the Study}

Capital investment decisions are vital at both firm level and national level (Northcott, 1995): at the firm level, capital investment decisions would have implications for many aspects of company operations and the results have a crucial effect on survival, profitability and growth. At the national level, healthy planning and allocation of capital investment are crucial for an efficient use of other resources; on the other hand, poor investment negatively affects the productivity of labour, materials and the economy's potential output. Therefore, this study receives significant attention.

Over the last decades, there has been a dramatic change observed in the environment milieu, where the organisation operates on presenting new opportunities as well as threats to practitioners and managers (Verbeeten, 2006). Uncertainties such as unpredictable changes in exchange rates, interest rates, and prices of goods cannot be ignored. Increased volatility in unpredictable changes would create more cut-throat competition than ever before (Smith, Smithson and Wilford, 1989). In some countries, the increase in lawsuits for liability on products can adversely affect the organisation by the increasing cost of liability insurance. In addition, Prahalad (1994) expressed that 'corporate governance' creates new uncertainties in large organisations. The concept of governance includes many interlinked aspects of corporate control, corporate policy, and corporate structure, the distribution of income among shareholders and specifically, the goals of companies. However, it is important to recognise the interest of stakeholders other than shareholders (such as suppliers, customers, employees and the wider community) or there may be serious financial consequences (Verbeeten, 2006). All of these developments and changes nurture a new financial environment, markets and governance structures in the way that organisations work. Therefore, change in use of capital budgeting methods is challenging but also vital for competition with other organisations. There is a strong believe in finance literature that effective investment decision making leads to 


\section{Mll Macrothink}

International Journal of Accounting and Financial Reporting ISSN 2162-3082 2017, Vol. 7, No. 2

higher performance to the respective companies (e.g., Kim, 1981; Haka, Gordon and Pinches, 1985; Ho, 1992; Chen, 1995; Dardanne, 1998, Farragher, Kleiman and Sahu, 2001; Gomes, Yasin and Lisboa, 2011; Jiang, Chen and Huang, 2006). But specifically political, policy and social uncertainties are the dominant aspects which change the use of capital budgeting practices. Political uncertainties including Terrorism, War, Changes in Government, Political instability are interacting the relationship between the capital budgeting decisions and performance (Verbeeten, 2006). Due to this reasons, the evaluating moderating effect of uncertainties between capital budgeting practice and performance is examined in this study.

\section{Theoretical View on Ccorporate Finance Theory and Corporate Performance}

Capital budgeting is a major terrain of the sphere of financial management. Although capital budgeting involves the investment of a present sum of funds in an efficient and effective way to generate future fund flows in the long term (Quirin, 1967), different authors define capital budgeting in different ways. Gitman, Juchau and Flanagan (2010) define capital budgeting as "the process of evaluating and selecting long term investment consistent with the firm owners' goal of wealth maximization" (p.344). Traditional financial theory states that the application of sophisticated capital budgeting techniques will result in improved corporate performance (e.g., Copeland, 1979). Capital budgeting decisions are among the most critical for a firm's performance and future prospects (Rigopoulos, 2014). Capital budgeting is derived from the concept of maximizing a firm's value because capital investment projects are supposed to maximize the value added to the stockholders (Hermes, Smid and Yao, 2007). The performance of a firm depends on its investment decisions. Investing in the 'right' project has an influence on the success of the firm and its future growth.

Organisations have many goals and objectives, such as survival and sustainability, profit maximisation, shareholder value growth, sales growth, quality, innovation and social responsibility (Emmanuel, Otley and Merchant, 1995). Many studies have found that sophisticated capital budgeting practices positively influence firms' performance (e.g., Kim, 1981; Haka, Gordon and Pinches, 1985; Ho, 1992; Chen, 1995; Dardanne, 1998, Farragher, Kleiman and Sahu, 2001; Jiang, Chen and Huang, 2006; Gomes, Yasin and Lisboa, 2011).

Capital budgeting investment of firms involved large sums of money over the long periods are crucial for the sustaining, surviving and flourishing in markets (Emmanuel, Harris and Komakech, 2010; Ghahremani, Aghaie and Abedzadeh, 2012), decisions on capital budgeting investments are critical owing to the influence of uncertainty factors (e.g., Peterson and Fabozzi, 2002, Cooper et al., 2002; Dayananda et al., 2002; Ghahremani, Aghaie and Abedzadeh, 2012). The global financial crisis epitomised this truth. The sources of uncertainty range from the mundane (such as cash flow estimation, number and sources of estimation error) to the more esoteric (such as complementarities among investments, options presented by investment opportunities, opportunity cost of investments) (Haka, 2006). One of the most intractable issues confronted by researchers is how to identify, capture, and evaluate uncertainties associated with long term investment projects (Haka, 2006). Considering the importance of investment decisions nowadays, complex methods are used for making capital budgeting decisions rather than purely depending on theories of capital budgeting to mitigate 
the effect of uncertainty and other contingency factors (Arnold and Hatzopoulos, 2000; Cooper et al., 2002; Byrne and Davis, 2005; Verbeeten, 2006; Zhang, Huang and Tang, 2011; Kersyte, 2011; Bock and Truck, 2011; Singh, Jain and Yadav, 2012). Therefore aim of the study is to evaluate the interacting effect of uncertainty between capital budgeting practices and performance. There is only flimsy evidence in extant literature to support the impact of capital budgeting techniques on firm performance (e.g., Kim, 1981; Pike, 1988; Farragher, Kleiman and Sahu, 2001; Jiang, Chen and Huang, 2006; Vadeei et al., 2012)

Therefore this study evaluates the moderating effect of uncertainty between capital budgeting practices and performance. So, study is an endeavour to build on earlier findings examining the factors influencing capital budgeting practices (Aggarwal, 1980; Schall and Sundem, 1980; Scapens and Sale, 1981; Kim, 1981; Mukherjee and Henderson, 1987; Haka, 1987; Klammer,Koch and Wilner,1991; Staw, 1991;Ho and Pike, 1992; Nutt, 1993; Sangster, 1993; Chen, 1995; Slagmulder, 1997; Bowman and Moskowitz, 2001; Zhu and Weyant, 2003; McGrath and Nerkar, 2004; Verbeeten, 2006; Donker, Santen, Zahir (2009); Brown and Sarma, 2007; Glaser, Schafers, and Weber, 2008, Daunfeldt and Hartwig,2011).

Uncertainty takes different forms: business uncertainty and project uncertainty (Townsend, 1969); market uncertainty and company uncertainty (Seidler and Carmichael, 1981); static and dynamic uncertainty (Fanning, 1983); strategic, operational and financial uncertainty (Vojta, 1992); general, industry and firm uncertainty (Miller, 1992); direct and indirect uncertainty (Pringle and Cannolly, 1993); aggregate uncertainty and firm-specific or idiosyncratic uncertainty (Dixit and Pindyck,1994); business and financial uncertainty (Baril, Benke and Buetow, 1996); endogenous and exogenous uncertainty (Folta, 1998); market, industry and firm specific uncertainty (Bulan, 2005); input uncertainty, financial uncertainty, social uncertainty and market uncertainty (Verbeeten, 2006).

\subsection{Social Uncertainty}

According to Verbeeten in 2006, social uncertainty includes political (Terrorism, War, Changes in Government, Political instability) policy uncertainty (Fiscal and monetary policies, Trade restrictions, regulations affecting the business sector, Tax policy) and Social unrest, Shift in social concerns, beliefs, values and attitudes reflected in current government policy or business practice. Political uncertainty is especially detrimental for attracting foreign direct investment that is vital for the country's economic growth. Foreign investors prefer a stable political environment, with less policy uncertainty and assurance of property rights. A high degree of political uncertainty created by possibilities of changes of government that may bring drastic economic policy changes is detrimental to investment.

Of these different types of uncertainty, social uncertainty has been considered in this study to evaluate the moderating effect of uncertainty between capital budgeting and performance which leads to research question:

Do uncertainties moderate the relationship between capital budgeting practices and performance? 


\section{Ml Macrothink}

International Journal of Accounting and Financial Reporting

ISSN 2162-3082

2017, Vol. 7, No. 2

Thus, it can be hypothesised that $\left(\mathrm{H}_{1}\right)$ : Uncertainties moderate the relationship between capital budgeting practices and firms' performance i.e., the relationship between capital budgeting practices and firms' performance will be weakened for firms that experience higher levels of uncertainty than those that experience low levels of uncertainty. As explained in the literature above, only sophisticated and advanced capital budgeting practices will be considered to evaluate the moderating effect as those are leading to the firm performances.

\section{Materials and Methods}

\subsection{Participants}

Companies operating more than five years would be congenial and strongly represent capital budgeting practice in terms of uncertainty factors. Thus, rather than selecting few companies and generalizing findings to other companies, it is better to select population since it has just 287 companies listed on Colombo Stock Exchange (CSE) in Sri Lanka as in June 2013, of which 186 companies' CFOS were responded to this survey.

\subsection{Data Collection}

Field work was carried to collect the primary data using different ways from June to November 2013. The self-reporting structured questionnaire was used to collect the data from all listed companies and questionnaire included the straight forward cover letter to the Chief Financial Officers of companies to emphasize confidentiality, reason for conducting survey and beneficial nature of research to practitioners and academics.

\subsection{Measurement Variables}

\subsubsection{Uncertainty}

Miller (1992) uncertainty framework and Verbeeten (2006) uncertainty factors have been considered to measure the social uncertainty factors in this study to evaluate the moderating effect of uncertainty between capital budgeting practices and performance. As indicated in the Table 1, following uncertainty factors treated as social uncertainty in the literature (Verbeeten, 2006)

Table 1. Uncertainty and its components

\begin{tabular}{|c|c|c|}
\hline $\begin{array}{l}\text { Social } \\
\text { uncertainty }\end{array}$ & Description & $\begin{array}{c}\text { Verbeeten's (2006) } \\
\text { model }\end{array}$ \\
\hline Political & $\begin{array}{l}\text { Terrorism, War, Changes in Government, } \\
\text { Political instability }\end{array}$ & Social uncertainties \\
\hline $\begin{array}{l}\text { Government } \\
\text { policy }\end{array}$ & $\begin{array}{l}\text { Fiscal and monetary policies, Trade } \\
\text { restrictions, regulations affecting the business } \\
\text { sector, Tax policy }\end{array}$ & $\begin{array}{l}\text { include } \\
\text { Political uncertainty } \\
\text { Society uncertainty }\end{array}$ \\
\hline Social & $\begin{array}{l}\text { Social unrest, Shift in social concerns, beliefs, } \\
\text { values and attitudes reflected in current } \\
\text { government policy or business practice. }\end{array}$ & Policy uncertainty \\
\hline
\end{tabular}




\section{Mll Macrothink}

International Journal of Accounting and Financial Reporting

ISSN 2162-3082

Participants was asked to indicate on a 5-point Likert scale (ranging from $1=$ not at all important, to $5=$ very important) to what extent they consider social uncertainties relevant for their company within the time frame of an investment decision.

\subsubsection{Capital Budgeting Practices}

Capital budgeting practices was measured with questionnaire originally developed and validated by (Graham and Harvey, 2001; Brounen, deJong and Koedijk., 2004; Verma,Gupta and Batra, 2009). Respondents was asked to indicate on a 5-point Likert scale (ranging from $1=$ never, to $5=$ always) to what extent they consider several capital budgeting techniques useful or important in the investment process.

\subsubsection{Performance}

Performance has been measured by Tobin_Q measure. Tobin's q confines the essence of the application of sophisticated capital budgeting techniques (Perfect and Wiles, 1994). In order to get the maximum value out of the input, this ratio was applied as a measure of performance in line with Axelsson, Jakovicka, and Kheddache (2002).

Tobin's q is in this model defined (Perfect and Wiles, 1994) as:

$$
q=\underline{\text { Maket Value of Equity }+ \text { DEBT }}
$$

Total Assets

\subsection{Testing the Reliability}

A reliability analysis of the item-scales was performed using SPSS. Cronbach's alpha $(\alpha)$ values were assessed for each variable with item-scales. The reliability of the test is reported in Table 2. The reliability of the measures was well above the minimum threshold of 0.60 in every case (Gliner and Morgan, 2000). Thus, it can be concluded that all of the measures were generally reliable.

Table 2. Testing the reliability

\begin{tabular}{lcc}
\hline \multicolumn{1}{c}{ Dimensions of variables } & $\begin{array}{c}\text { No. of } \\
\text { dimensions }\end{array}$ & $\begin{array}{c}\text { Cronbach's } \\
\text { Alpha ( } \boldsymbol{\alpha})\end{array}$ \\
\hline $\begin{array}{l}\text { Capital budgeting methods (capital budgeting methods } \\
\text { and supplementary capital budgeting methods) }\end{array}$ & 28 & 0.636 \\
\hline $\begin{array}{l}\text { Social uncertainty factors (political, policy and social } \\
\text { uncertainties) }\end{array}$ & 6 & 0.668 \\
\hline
\end{tabular}

Source: survey data 


\section{Data Analysis}

\subsection{Principal Component Analysis (PCA) for Capital Budgeting Practices}

PCA was carried out to extract the capital budgeting practice as grouped in the literature. After some rounds of removing the unsuitable variables from anti image matrix the results that the remaining variables are grouped into three factors. Here KMO and Bartlett's test of Sphericity measure of sampling adequacy (George and Mallery, 2003) was used. A measure of sampling adequacy of 0.888 with a value of Bartlett's test of Sphericity (1221.845) with a high significant level $(\mathrm{P}<0.01)$, indicates the suitability of factor analysis. Table 3 illustrate the PCA's summarised output and all the variables' factor loadings were greater than 0.65 .

Table 3. Total variance explained for factors indicating to the capital budgeting practices

\begin{tabular}{lccc}
\hline \multirow{2}{*}{ Variables } & \multicolumn{3}{c}{ Component } \\
\cline { 2 - 4 } & $\begin{array}{c}\text { Advanced / NPV } \\
\text { Based Capital } \\
\text { Budgeting Practices }\end{array}$ & $\begin{array}{c}\text { Sophisticated } \\
\text { Capital } \\
\text { Budgeting } \\
\text { Practices }\end{array}$ & $\begin{array}{c}\text { Simple/ Naïve } \\
\text { Capital } \\
\text { Budgeting } \\
\text { Practices }\end{array}$ \\
\hline Eigen Value & 5.822 & 2.108 & 1.365 \\
Proportion of Variance Explained & $38.815 \%$ & $14.052 \%$ & $9.101 \%$ \\
Cumulative Percentage Explained & $38.815 \%$ & $52.867 \%$ & $61.968 \%$ \\
Cronbach's Alpha - Reliability of & 0.890 & 0.809 & 0.744 \\
factors & & & \\
\hline
\end{tabular}

As shown in the Table 3, the variables of capital budgeting practices grouped into related factor. The result illustrates that the variables that are grouped in three factors as the reviewed literature: Advanced/ NPV based capital budgeting practices including the variables of probability analysis, IRR, scenario analysis, breakeven analysis, uncertainty absorption in cash flows, sensitivity analysis and NPV, sophisticated capital budgeting practices covering the variables of real option, CAPM/B analysis, game theory decisions and decision trees and simple / NAÏVE capital budgeting practices including DPB, ARR and PB. Findings of this study underpinning with the theoretical base and consisting with study of Verbeeten (2006) and Wolffsen (2012).

\subsection{Descriptive Analysis}

The Table 4 shows descriptive statistics of the variables which consists values of minimum, maximum, mean and standard deviation of the independent, dependent variables. As indicated that the measure of uncertainty (ranging from $1=$ not at all important, to $5=$ very important) and capital budgeting variables (ranging from $1=$ never to $5=$ always) were measured by 5 point Likert scale ranging from 1-5. 
Table 4. Descriptive analysis of the variables 2017, Vol. 7, No. 2

\begin{tabular}{llllll}
\hline & $\mathrm{N}$ & Minimum & Maximum & Mean & $\begin{array}{l}\text { Std. } \\
\text { Deviation }\end{array}$ \\
\hline $\begin{array}{l}\text { Sophisticated capital budgeting practices } \\
\text { Advanced/NPVBased capital budgeting }\end{array}$ & 186 & 1.00 & 3.25 & 1.3091 & .47916 \\
$\begin{array}{l}\text { practices } \\
\text { Simple/NAÏVE capital budgeting practices }\end{array}$ & 186 & 1.57 & 5.00 & 3.9209 & .64694 \\
Social uncertainty & 186 & 1.00 & 4.00 & 3.1900 & .63131 \\
Tobin_q & 186 & 0.27 & 32.19 & 2.1383 & 2.7403 \\
\hline
\end{tabular}

As per the result of descriptive analysis reported in the table 4, advanced/NPV based capital budgeting practices have highest value of 5 which consist of mean value is 3.9209. Social uncertainty has mean value of 3.5627 and mean value of Tobin_q is 2.1383 .

\subsection{Correlations between Capital Budgeting Practices and Firm Performance}

A correlation analysis was performed between capital budgeting practices (sophisticated, advanced and naive capital budgeting practices) and firm performance (effectiveness, and Tobin_q). Table 5 presents the results of the correlation analysis.

Table 5. Correlation analysis between capital budgeting practices and performance

\begin{tabular}{lllll}
\hline & 1 & 2 & 3 & 4 \\
\hline \hline 1.Sophisticated_CBP & 1.000 & & & \\
2.Advanced_CBP & $.402^{* * *}$ & 1.000 & & \\
3.Naive_CBP & $-.448^{* * * *}$ & $-.433^{* * *}$ & 1.000 & \\
4.Tobin_q & $.376^{* * *}$ & $.289^{* * *}$ & $-.196^{* * *}$ & 1.000 \\
\hline \hline
\end{tabular}

As shown in Table 5, sophisticated capital budgeting practices are significantly positively associated with Tobin_q $(r=.376, p<0.01)$. Advanced capital budgeting practices are significantly positively associated with Tobin_q $(r=.289, p<0.01)$. There is a negative significant association between naive capital budgeting practices and Tobin_q $(r=-.196, p<$ $0.01)$.

\subsection{Analysis of Moderating Effect}

An additional analysis on the moderating effect was employed by dint of Andrew Hayes' "process.spd", as suggested by Hayes (2013) and Field (2013). Moderation is a combined effect of two variables (interaction effect) and thus the model includes at least one predictor, a moderator and predictor $\mathrm{x}$ moderator (interaction term). If the interaction term is significant, the variable is said to be a moderator. 


\section{MIN Macrothink}

International Journal of Accounting and Financial Reporting

ISSN 2162-3082

2017, Vol. 7, No. 2

4.4.1 Social Uncertainty as a Moderator of the Relationship between Sophisticated Capital Budgeting Practices and Tobin_q

This section examines whether social uncertainty will moderate the relationship between sophisticated capital budgeting practices and Tobin-q (firms' performance) i.e., the relationship between sophisticated capital budgeting practices and Tobin-q will be weakened for firms that experience higher levels of social uncertainty than those that experience lower levels of social uncertainty. The result of the moderator analysis is presented in Table 6 .

Table 6. Social uncertainty as a moderator between sophisticated capital budgeting practices and Tobin_q

\begin{tabular}{lcccc}
\hline \hline & $b$ & $S E B$ & $t$ & $P$ \\
\hline \hline Constant & $-.01(-.12, .12)$ & .0612 & -.0196 & $p=.9844$ \\
Social Uncertainty (centred) & $-.40(-.60,-.20)$ & .1021 & -3.8853 & $p=.0001$ \\
Sophisticated CBP (centred) & $.41(.24, .58)$ & .0869 & 4.7519 & $p=.0000$ \\
Sophisticated CBP X Social uncertainty & $-.32(-.60,-.04)$ & .1428 & -2.2184 & $p=.0278$ \\
\hline \hline
\end{tabular}

As can be seen in Table 6, the interaction term (Sophisticated CBP X Social uncertainty) is significant, $b=-.32, t=-2.2184, p=0.0278$ indicating that the relationship between sophisticated capital budgeting practices and Tobin-q is moderated by social uncertainty i.e., social uncertainty weakens the positive relationship between sophisticated capital budgeting practices and Tobin-q. Furthermore, the results of the slope analysis and the nature of moderating effect are depicted in Figure 1.

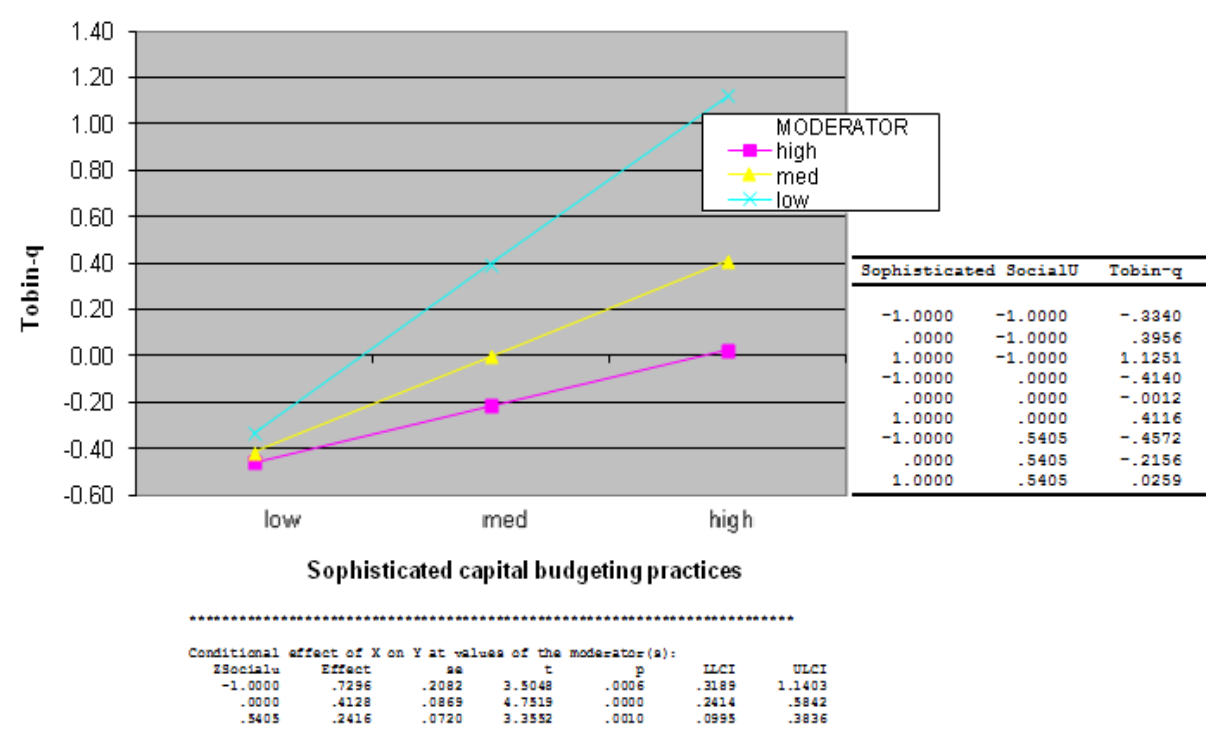

Figure 1. Graphical presentation of social uncertainty as a moderator between sophisticated capita budgeting practices and Tobin_q 


\section{Mll Macrothink}

International Journal of Accounting and Financial Reporting

ISSN 2162-3082

2017, Vol. 7, No. 2

The result of the conditional effect of sophisticated capital budgeting practices on Tobin_q for the different levels of social uncertainty is presented at the bottom of figure 1. According to the figure, there are three different regressions: the regression for sophisticated capital budgeting practices as a predictor of Tobin-q (1) when social uncertainty is low (value of social uncertainty is -1.000); (2) at the mean value of social uncertainty (the value is zero because of centred traits); and (3) when the value of social uncertainty is high (value of traits is .5405). When social uncertainty is low, there is a significant positive relationship between sophisticated capital budgeting practices and Tobin-q, $b=.73,95 \% C I(0.32,1.14), t=$ $3.5048, p<0.05$, whilst at the mean value of social uncertainty the relationship between sophisticated capital budgeting practices and Tobin-q is significantly positive. However, this relationship is weaker than at a low level of social uncertainty, $b=.41,95 \% C I(0.24, .58), t=$ $4.7519, p<0.05$. Similarly, when social uncertainty is high there is still a significant positive relationship between sophisticated capital budgeting practices and Tobin-q. However, this relationship is weaker than at the mean level of social uncertainty, $b=.24,95 \% C I(.10,0.38)$, $t=3.3552, p<0.05$. Overall, the results reveal that there is a significant positive relationship between sophisticated capital budgeting practices and Tobin-q at all three levels of social uncertainty; nonetheless, this positive relationship is weakened when the level of social uncertainty increases. It is shown in Figure 1 that the positive relationship between sophisticated capital budgeting practices and Tobin-q is stronger at low levels of social uncertainty than at average or higher levels of social uncertainty.

4.4.2 Social Uncertainty as a Moderator of the Relationship between Advanced Capital Budgeting Practices and Tobin_q

The section examines whether the social uncertainty will moderate the relationship between advanced capital budgeting practices and Tobin_q (firms' performance) i.e., the relationship between advanced capital budgeting practices and Tobin_q will be weakened for firms that experience higher levels of social uncertainty than those that experience low levels of social uncertainty. The result of the moderator analysis is presented in Table 7.

Table 7. Social uncertainty as a moderator between advanced capital budgeting practices and Tobin_q

\begin{tabular}{lcccc}
\hline \hline & $b$ & $S E B$ & $t$ & $p$ \\
\hline \hline Constant & $.01(-.12, .13)$ & .0641 & .0243 & $p=.9806$ \\
Social Uncertainty (centred) & $-.39(-.57,-.20)$ & .0956 & -4.0288 & $p=.0001$ \\
Advanced CBP (centred) & $.27(.15, .39)$ & .0628 & 4.2831 & $p=.0000$ \\
Advanced CBP X Social uncertainty & $-.25(-.49,-0.01)$ & .1219 & -2.0307 & $p=.0437$ \\
\hline \hline
\end{tabular}




\section{MIN Macrothink}

International Journal of Accounting and Financial Reporting

ISSN 2162-3082

2017, Vol. 7, No. 2

As can be seen in Table 7, the interaction term (Advanced CBP X Social uncertainty) is significant, $b=-.25, t=-2.0307, p=0.0437$ indicating that the relationship between advanced capital budgeting practices and Tobin_q is moderated by social uncertainty i.e., social uncertainty weakens the positive relationship between advanced capital budgeting practices and Tobin_q. Furthermore, the results of the slope analysis and the nature of moderating effect are depicted in Figure 2.

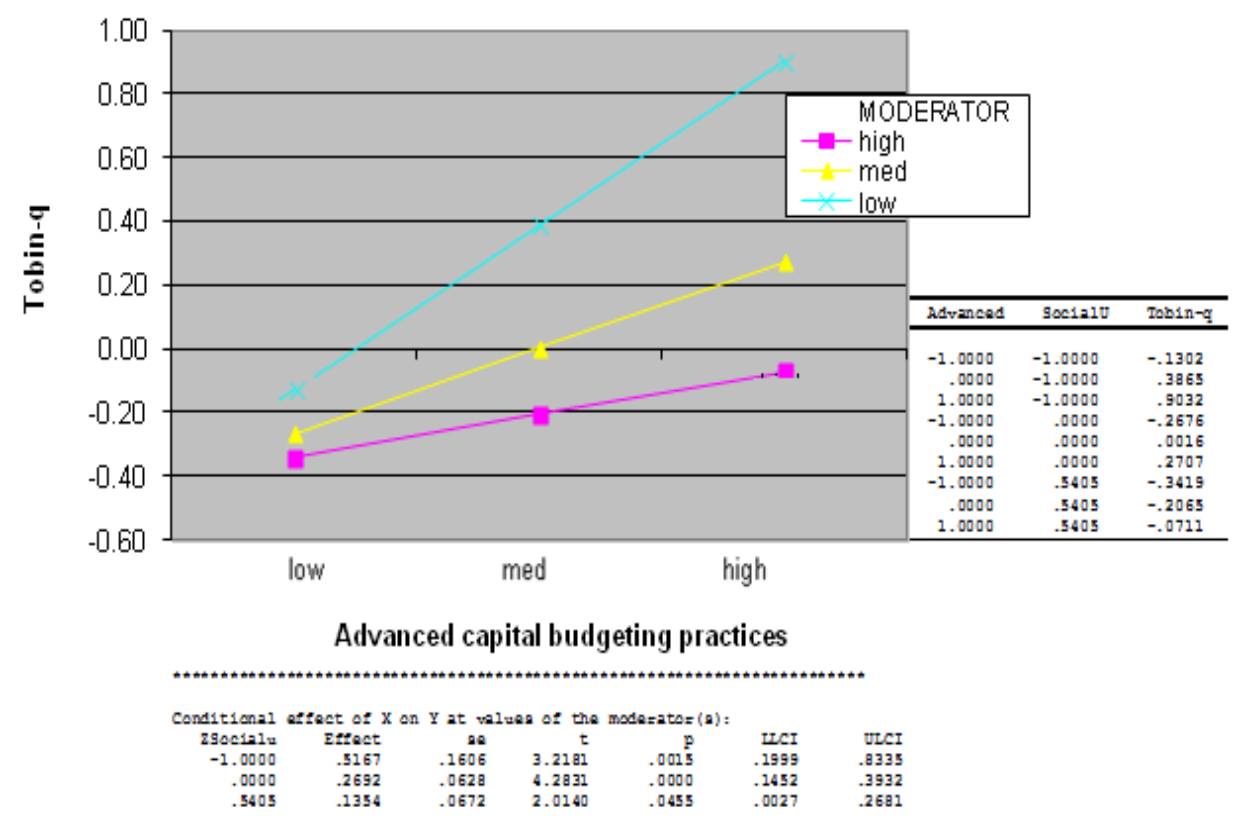

Figure 2. Graphical presentation of social uncertainty as a moderator between advanced capita budgeting practices and Tobin_q

The result of the conditional effect of advanced capital budgeting practices on effectiveness for the different levels of the social uncertainty is presented at the bottom of figure 2 . According to the figure, there are three different regressions: the regression for advanced capital budgeting practices as a predictor of Tobin_q (1) when social uncertainty is low (value of social uncertainty is -1.000); (2) at the mean value of social uncertainty (the value is zero because of centred traits), and (3) when the value of social uncertainty is high (value of traits is .5405). When social uncertainty is low, there is a significant positive relationship between advanced capital budgeting practices and Tobin_q, $b=.52,95 \% C I(.20, .83), t=$ $3.2182, p<0.05$ whilst at the mean value of social uncertainty, the relationship between advanced capital budgeting practices and Tobin_q is significantly positive. However, this relationship is weaker than at a low level of social uncertainty, $b=.27,95 \% C I(.15, .39), t=$ $4.2831 p<0.05$. Similarly, when social uncertainty is high there is still a significant positive relationship between advanced capital budgeting practices and Tobin_q. However, this relationship is weaker than at the mean level of social uncertainty, $b=.14,95 \% C I$ $(.002, .27), t=2.0140, p<0.05$. Overall, the results reveal that there is a significant positive 
relationship between advanced capital budgeting practices and Tobin_q at all three levels of social uncertainty; nonetheless, this positive relationship is weakened when the level of social uncertainty increases. It is shown in figure 2 that the positive relationship between advanced capital budgeting practice and Tobin_q is stronger at a low level of social uncertainty than at the average or a high level of social uncertainty.

4.4.3 Social Uncertainty as a Moderator Of the Relationship between Naive Capital Budgeting Practices and Tobin_q

There was no any statistically significant moderating effect of social uncertainty between naive capital budgeting practices and Tobin_q. That's why result was not reported here.

Therefore, hypothesis $\left(\mathrm{H}_{1}\right)$ that uncertainties moderate the relationship between capital budgeting practices and firms' performance i.e., the relationship between capital budgeting practices and firms' performance will be weakened for firms that experience higher levels of social uncertainty than those that experience low levels of uncertainty was supported in the following ways:

- Social uncertainty moderates the relationship between sophisticated capital budgeting practices and Tobin_q. That is, an increased level of social uncertainty weakens the positive relationship between sophisticated capital budgeting practices and Tobin_q and vice versa.

- Social uncertainty moderates the relationship between advanced capital budgeting practices and Tobin_q. That is, an increased level of social uncertainty weakens the positive relationship between advanced capital budgeting practices and Tobin_q and vice versa.

Therefore, hypothesis supported in this study and also naive capital budgeting practices were not considered in hypothesis testing as sophisticated and advanced capital budgeting practices are mostly influence to performances.

\section{Conclusion}

Aim of this study was to evaluate the interacting effect of uncertainty between capital budgeting practices and performance based on Sri Lankan emerging market. The data for this study were garnered from primary data and secondary data sourcesa. The primary data were collected from 186 CFOs working in companies listed on the Colombo Stock Exchange using self-administered questionnaires. The questionnaire was piloted with a sample of five CFOs. The secondary data were mainly collected from CSE via the Bloomberg website/annual reports for the 5 years period. Performance was measured by Tobin_q After the data were collected, they were analysed using statistical tools.

Social uncertainty such as policy (regulations affecting the business sector, tax policy), political issues (terrorism, war, changes in government, political instability) and social factors (social unrest, shift in social concerns, beliefs, values and attitudes reflected in current government policy or business practice) were considered in this study. It does moderate firms' performance together with their capital budgeting practices in two ways: 1) Social 


\section{Mll Macrothink}

International Journal of Accounting and Financial Reporting ISSN 2162-3082 2017, Vol. 7, No. 2

uncertainty moderates the relationship between sophisticated capital budgeting practices and Tobin_q. That is, an increased level of social uncertainty weakens the positive relationship between sophisticated capital budgeting practices and Tobin_q and vice versa.)Social uncertainty moderates the relationship between advanced capital budgeting practices and Tobin_q. That is, an increased level of social uncertainty weakens the positive relationship between advanced capital budgeting practices and Tobin_q and vice versa. Overall, this study has made contribution as identified the interacting effect of uncertainty between the relationship of capital budgeting practices and performances. There was no previous evidence to see moderating effect of uncertainty between the capital budgeting and performance. In a nutshell, beyond its valuable contribution, this study serves as a springboard for future research.

\section{References}

Aggarwal, R. (1980). Corporate Use of Sophisticated Capital Budgeting Techniques: A strategic Perspective and a Critique of Survey Results. Interfaces, 10(2), 31-34.

Arnold, G.C., \& Hatzopoulos, P.D. (2000). The theory-practice gap in capital budgeting: evidence from the United Kingdom. Journal of Business Finance and Accounting, 10(5), 603-626.

Axelsson, H, Jakovicka, J., \& Kheddache, M. (2002). Capital budgeting sophistication and performance: A puzzling relationship. Unpublished Master Thesis, Graduate Business School, Goteborg University.

Baril, C.P., Benke, R.L., \& Buetow, G.W. (1996). Managing Risk with Derivatives. Management Accounting, 20-27.

Bock, K., \& Truck, S. (2011). Assessing uncertainty and risk in public sector investment projects. Technology and Investment, 2(2), 105-123.

Bowman, E.H., \& Moskowitz, G.T. (2001). Real options analysis and strategic decision making. Organizations Science, 12(6), 772-777.

Brounen, D., de Jong, A., \& Koedijk, K. (2004). Corporate finance in Europe: Confronting theory with practice. Financial Management, 33(4), 71-101.

Brown, R., \& Sarma, N. (2007). CEO Overconfidence, CEO Dominance and Corporate Acquisitions. Journal of Economics and Business, 59(5), 358-379.

Bulan, L.T. (2005). Real options, irreversible investment and firm uncertainty: New evidence from U.S. firms. Review of Financial Economics, 14(3), 255-279.

Byrne, J.P., \& Davis, E.P. (2005). Investment and Uncertainty in the G7. Review of World Economics, 141(1), 1-32.

Chen, S. (1995). An Empirical Examination of Capital Budgeting Techniques: Impact of Investment Types and Firm Characteristics. The Engineering Economist, 40(2), 145-170. 


\section{Mll Macrothink}

International Journal of Accounting and Financial Reporting

ISSN 2162-3082

2017, Vol. 7, No. 2

Cooper, W.D., Morgan, R.G., Redman ,A., \& Smith, M. (2002). Capital Budgeting Models: Theory vs. Practice. Business Forum- Los Angeles (California State University), 26(1/2), $15-19$.

Copeland, T. E. (1979). Financial Theory and Corporate Policy $\left(1^{\text {st }}\right.$ ed.). Wesley, Reading: Addison-Wesley Publishing Company, Inc.

Dardenne, P. (1998). Capital budgeting practices, procedures and techniques by large companies in Belgium. Paper presented at the 21st Annual Congress of the European Accounting Association, Antwerp, Belgium

Daunfeldt, S. O., \& Hartwig, F. (2014). What determines the use of capital budgeting methods? Evidence from Swedish listed companies. Journal of Finance and Economics, 2(4), 101-112.

Dayananda, D., Irons, R., Harrison, S., Herbohn, J., \& Rowland, P. (2002). Capital Budgeting: Financial Appraisal of Investment Projects. Edinburgh: Cambridge University Press.

Dixit, A.K., \& Pindyck, R.S. (1994). Investment under Uncertainty. Princeton, New Jersey: Princeton University Press.

Donker, H., Santen, B., \& Zahir, S. (2009). Ownership structure and the likelihood of financial distress in the Netherlands. Applied Financial Economics, 19(21), 1687-1696.

Emmanuel, C., Otley, D., \& Merchant, K. (1995). Accounting for Management Control (2nd ed.). London: International Thomson Business Press.

Emmanuel, C., Harris, E., \& Komakech, S. (2010) .Towards a better understanding of capital investment decisions. Journal of Accounting and organizational change, 6(4), 477-504.

Farragher, E.J., Kleiman, R.T., \& Sahu, A.P. (2001). The association between the use of sophisticated capital budgeting practices and corporate performance. The Engineering Economist, 46(4), 300-311.

Field, A. (2013). Discovering statistics using IBM SPSS statistics (4th ed.). London: Sage Publications.

Folta, T.B. (1998). Governance and Uncertainty: The Trade-Off between Administrative Control and Commitment. Strategic Management Journal, 19(11), 1007-1028.

Ghahremani, M., Aghaie, A., \& Abedzadeh, M. (2012).Capital Budgeting Technique Selection through Four Decades: With a Great Focus on Real Option. International Journal of Business and Management, 7(17), 98-119

Gitman, L. J., Juchau, R., \& Flanagan, J. (2010). Principles of managerial finance. Pearson Higher Education AU.

Glaser, M., Schäfers, P., \& Weber, M. (2008). Managerial optimism and corporate investment: Is the CEO alone responsible for the relation?. In AFA 2008 New Orleans Meetings Paper. Retrieved from http://ssrn.com/abstract $=967649$ 


\section{Mll Macrothink}

International Journal of Accounting and Financial Reporting ISSN 2162-3082

Gliner, J.A., \& Morgan, G.A. (2000). Research methods in applied settings: an integrated approach to design \& analysis. Morwah, NJ: Lawrence Erlbaum

Gomes, C.F., Yasin, M.M., \& Lisboa, J.V. (2010). Performance measurement practices in manufacturing firms revisited. International Journal of Operations and Production Management, 31(1), 5-30.

Graham, J., \& Harvey, C. (2001). The theory and practice of corporate finance: evidence from the field. Journal of Financial Economics, 60(2-3), 187-243.

Haka, S. F. (2006).A review of the literature on capital budgeting and investment appraisal: past, present, and future musings. Handbooks of Management Accounting Research, 2, 697-728.

Haka, S.F. (1987). Capital Budgeting Techniques and Firm Specific Contingencies: A Correlational Analysis. Accounting, Organizations and Society, 12(1), 31-48.

Haka, S.F., Gordon, L.A., \& Pinches, G.E. (1985). Sophisticated capital budgeting selection techniques and firm performance. The Accounting Review, LX(4), 651-668.

Hayes, A. F. (2013). Introduction to mediation, moderation, and conditional process analysis: A regression-based approach. Guilford Press.

Hermes, N., Smid, P., \& Yao, L. (2007). Capital budgeting practices: A comparative study of the Netherlands and China. International Business Review, 16(5), 630-654.

Ho, S.S.M. (1992). The Impact of Using Risk Analysis in Capital Budgeting on Earnings Performance: the UK Experience. International Journal of Accounting, 27, 1-14.

Ho, S.S.M., \& Pike, R.H. (1998). Organizational characteristics influencing the use of risk analysis in strategic capital investment. The Engineering Economist, 43(3), 247-268.

Jiang, C.H., Chen, H.L., \& Huang, Y.S. (2006). Capital expenditures and corporate earnings: Evidence from the Taiwan Stock Exchange. Managerial Finance, 32(11), 853-861.

Kersyte, A. (2011).Capital budgeting process: Theoretical Aspects. Journal of Economics and Management, 16(1), 1130-1134.

Kim, S.H. (1981). An Empirical Study on the Relationship between Capital Budgeting practices and Earnings Performance. The Engineering Economist, 27(3), 185-196.

Klammer, T., Koch, B., \& Wilner, N. (1991). Capital Budgeting Practice- A Survey of Corporate Use. Journal of Management Accounting Research, 3(1),113-130.

McGrath, R.G., \& Nerkar, A. (2004). Real options reasoning and a new look at the R\&D investment strategies of pharmaceutical firms. Strategic Management Journal, 25(1), 1-21.

Miller, K.D. (1992). A Framework for Integrated Risk Management in International Business. Journal of International Business Studies, 23(2), 311-331. 


\section{MInstitute Macrothink $_{\text {Int }}$}

International Journal of Accounting and Financial Reporting

ISSN 2162-3082

Mukheijee, T.K., \& Henderson, G.V. (1987). Capital Budgeting Process: Theory and Practice. Interfaces, 17(2), 78-90.

Northcott, D. (1995). Capital Investment Decision-Making. London: The Dryden Press.

Nutt, P.C. (1993). Flexible Decision Styles and the Choices of Top Executives. Journal of Management Studies, 30(5), 695-721.

Perfect, S. B., \& Wiles, K.W. (1994). Alternative Constructions of Tobin's q: An Empirical Comparison. Journal of Empirical Finance, 1, 313-341.

Peterson, P. P., \& Fabozzi, F. J. (2002). Capital budgeting: theory and practice, Vol. 10. John Wiley \& Sons.

Pike, R.H. (1988). An empirical study of the adoption of sophisticated capital budgeting practices and decision making effectiveness. Accounting and Business Research, 18(72), 341-351.

Prahalad, C.K. (1994). Corporate Governance or Corporate Value Added?. Rethinking the primacy of Shareholder Value. Journal of Applied Corporate Finance, 6(4), 40-50.

Pringle, J.J., \& Connolly, R.A. (1993). The Nature and Causes of Foreign Currency Exposure. Continental Bank. Journal of Applied Corporate Finance, 61-72.

Quirin, G.D. (1967). The capital expenditure decision. New York: Richard D. Irwin Publication.

Rigopoulos, G. (2014). Real Options Adoption in Capital Budgeting: A Highlight of Recent Literature. Journal of Economics and Business Research, 20(2), 41-51.

Sangster, A. (1993). Capital investment appraisal techniques: A survey of current usage. Journal of Business Finance and Accounting, 20(3), 307-332.

Scapens, R.W., \& Sale, J.T. (1981). Performance Measurement and Formal Capital Expenditure Controls in Divisionalized Companies. Journal of Business Finance \& Accounting, 8(3), 389419.

Schall, L.D., \& Sundem, G.L. (1980). Capital Budgeting Methods and Risk: A Further Analysis. Financial Management, 9(1), 7-11.

Seidler, L.J., \& Carmichael, D.R. (1981). Accountants' Handbook. (6 ${ }^{\text {th }}$ ed.), Vol I \& II. John Wilcy \& Sons, Inc.

Singh, S., Jain, P.K., \& Yadav, S.S. (2012). Capital budgeting decisions: evidence from India. Journal of Advances in Management Research, 9(1), 96-112.

Slagmulder, R. (1997). Using Management Control Systems to Achieve Alignment between Strategic Investment Decisions and Strategy. Management Accounting Research, 8, 103-139.

Smith, C. W., Smithson, C. W., \& Wilford, D. S. (1989). Managing financial risk. Journal of Applied Corporate Finance, 1(4), 27-48. 


\section{MInstitute Macrothink $^{m}$}

International Journal of Accounting and Financial Reporting ISSN 2162-3082

Staw, B. M. (1991). Dressing Up Like an Organization: When Psychological Theories Can Explain Organizational Action. Journal of Management, 17(4), 805-819.

Townsend, E.C. (1969). Investment and Uncertainty: a Practical Guide. Edinburgh: Oliver and Boyd.

Vadeei, M., Mahmoudi, P., Khatibi, S.A., Mohammadi, J. (2012).An Analysis and Explanation of the Relationship between Techniques of Capital Budgeting and the Performance of Companies Admitted to Tehran Stock Exchange (Iran). Journal of Basic and Applied Scientific Research, 2(7), 6420-6423.

Verbeeten, F.H.M. (2006). Do organizations adopt sophisticated capital budgeting practices to deal with uncertainty in the investment decision? A research note. Management Accounting Research, 17(1), 106-120.

Verma, S., Gupta, S., \& Batra, R. (2009). A Survey of Capital Budgeting Practices in Corporate India. The Journal of Business Perspective, 13(3), 1-17.

Vojta, G.J. (1992). Build a Framework for Risk Management. Financial Executive, 6, 3-6.

Wernerfelt, B., \& Karnani, A. (1987).Competitive Strategy under Uncertainty. Strategic Management Journal, 8(2), 187-194.

Wolffsen, P. (2012). Modification of capital budgeting under uncertainty. Taikomoji ekonomika: sisteminiai tyrimai, (6/2), 143-159.

Zhang, Q., Huang, X., \& Tang, L.(2011). Optimal multinational capital budgeting under uncertainty. Computers and Mathematics with Applications, 62(12), 4557-4568.

Zhu, K., \& Weyant, J.P. (2003). Strategic decisions of new technology adoption under asymmetric information: a game-theoretic model. Decision Science, 34(4), 643-675.

\section{Copyright Disclaimer}

Copyright for this article is retained by the author(s), with first publication rights granted to the journal.

This is an open-access article distributed under the terms and conditions of the Creative Commons Attribution license (http://creativecommons.org/licenses/by/4.0/) 